Gut, 1973, 14, 187-190

\title{
Free perforation in Crohn's disease
}

\author{
DAVID M. STEINBERG ${ }^{1}$, W. TREVOR COOKE, AND J. ALEXANDER-WILLIAMS \\ From the Nutritional and Intestinal Unit, General Hospital, Birmingham
}

SUMMARY Free perforation is a rare complication of Crohn's disease. Seven cases were found in a total series of 360 in Birmingham. It occurs during an acute exacerbation of chronic disease, particularly in the presence of distal obstruction. The incidence of this complication may becoming less common and steroid therapy was not a precipitating factor. Primary resection of the perforated and distal obstructed bowel is likely to give the best results.

Free perforation into the peritoneal cavity has been considered to be an extremely rare complication of Crohn's disease. Crohn (1957) stated that 'free perforation never occurs-or at least I have not seen it'. However, since Arnheim (1935) first described a case there have been at least one hundred reports in the literature (Menguy, 1972).

Some authors have suggested that this condition occurs in acute ileitis (Crohn, 1965) while others maintain that it is part of the process of chronic Crohn's disease (Waye and Lithgow, 1967). Controversy also exists as to the best methods of surgical management for this critical condition.

\section{Materials and Methods}

This paper is a retrospective survey of seven cases out

${ }^{1}$ D.M.S. was supported by a grant from the Raine Research Foundation of the University of Western Australia.

Received for publication 6 December 1972. of a total of 360 cases of chronic Crohn's disease reviewed on one unit in Birmingham. The findings have been compared with previously reported series in the literature. In the seven cases in question and in over $80 \%$ of this series, histological confirmation of Crohn's disease has been obtained. The remainder of the cases have been diagnosed on the basis of prolonged clinical follow up, radiology, or a combination of the above methods. Cases with peritonitis due to rupture of a chronic abscess were not included in this series.

\section{Results}

A summary of the case histories of the seven patients is shown in the table. The sex distribution was four male: three female and the ages ranged from 17 to 66. These were representative of the distribution of patients in the entire series.

It will be noted that the ileum was the site of the perforation in four, the jejunum, a bypassed ileal

\begin{tabular}{|c|c|c|c|c|c|c|c|c|}
\hline Sex & $\begin{array}{l}\text { Age } \\
\text { (yr) }\end{array}$ & Year & $\begin{array}{l}\text { Length of Previous } \\
\text { History }\end{array}$ & $\begin{array}{l}\text { Previous Opera- } \\
\text { tions and Time } \\
\text { Interval }\end{array}$ & $\begin{array}{l}\text { Previous Steroid } \\
\text { Therapy }\end{array}$ & Site of Perforation & Treatment & Outcome \\
\hline $\mathbf{M}$ & 36 & 1943 & $? 2 \mathrm{yr}$ & None & No & Jejuno-ileum & $\begin{array}{l}\text { Perforation } \\
\text { closed }\end{array}$ & Died \\
\hline $\mathbf{F}$ & 66 & 1950 & $2 \mathrm{yr}$ & Bypass 5/12 ago & No & $\begin{array}{l}\text { In bypassed ileal } \\
\text { loop }\end{array}$ & Resected & Died \\
\hline $\mathbf{M}$ & 17 & 1955 & $3 / 12$ & None & No & Ileum & $\begin{array}{l}\text { Perforation } \\
\text { closed }\end{array}$ & $\begin{array}{l}\text { Fistula then } \\
\text { recovered }\end{array}$ \\
\hline $\mathbf{F}$ & 37 & 1959 & $2 \mathrm{yr}$ & None & No & Ileum & Resected & $\begin{array}{l}\text { Recovered; } \\
\text { recurrence at } 12 \mathrm{yr}\end{array}$ \\
\hline $\mathbf{M}$ & 23 & 1960 & Over 6 yr & $\begin{array}{l}\text { Resection } 6 \text { years } \\
\text { ago }\end{array}$ & Yes & Ileum & Resected & $\begin{array}{l}\text { Recovered; } \\
\text { recurrence at } 2 \text { yr }\end{array}$ \\
\hline $\mathbf{F}$ & 34 & 1966 & Over 4 yr & $\begin{array}{l}\text { Ileocaecal } \\
\text { resection } 10 \text { days } \\
\text { ago }\end{array}$ & Yes & $\begin{array}{l}\text { Sigmoid } \\
\text { colon }\end{array}$ & Ileostomy & Recovered well \\
\hline $\mathbf{M}$ & 29 & 1972 & $1 \mathrm{yr}$ & $\begin{array}{l}\text { Appendicectomy } \\
20 \text { years ago }\end{array}$ & No & Ileum & Resection & Recovered well \\
\hline
\end{tabular}

Table Details of seven patients with free perforation (Birmingham series) 
loop, and the sigmoid colon in one each. The perforation of sigmoid colon occurred only 10 days after a right hemicolectomy for ileo-caecal Crohn's disease in which there was a difficult pelvic dissection. The perforation, however, was in a site of proven colonic Crohn's disease and macroscopically had the typical appearance of free perforation.

Two patients had been receiving steroids and five had none. Three had had previous operations for Crohn's disease and four had not.

In two patients an attempt was made to close the perforation; one died and the other was left with a permanent fistula. Four patients had a resection and anastomosis of the perforated segment and distal area of chronic Crohn's disease: three did well. The patient who perforated a bypassed loop of ileum was operated on in 1950; the resection was probably inadequate and the anastomosis leaked. With modern management this patient might not have died. One patient had a temporary defunctioning ileostomy and did well.

The year of occurrence of the seven perforations is shown with respect to the yearly rate of major 'curative' operations for Crohn's disease (that is resection or bypass) over 30 years in Figure.

\section{Discussion}

INCIDENCE

In many reported series the true incidence of free perforation is difficult to assess due to inability in distinguishing it from rupture of an intraabdominal abscess. There have been five reports of series of patients with chronic Crohn's disease in which the incidence of the complication has been recorded (Atwell, Duthie, and Goligher, 1965; Schofield, 1965; Gjone, Orning, and Myren, 1966; Koutny, 1968; Banks, Zetzel, and Richter, 1969). Of this total of 603 patients, six free perforations were recorded. This gives an incidence of approximately $1 \%$. In our series seven cases out of 360 represents approximately $2 \%$. The sex and age distribution in our series were similar to those in previous reports.

ACUTE OR CHRONIC DISEASE?

A low-grade granulomatous process with transmural inflammatory reaction is characteristic of Crohn's disease. It causes affected intestinal loops to become attached to adjacent structures, providing a pathological basis for the more common complications of abscess and fistula formation. While perforation may occur during an active phase of the disease it does not appear to occur in patients with 'acute ileitis' as was suggested by Crohn (1965). No perforations have been reported in the series of acute ileitis reported by Atwell and colleagues (1965), Schofield (1965),
Gump, Lepore, and Barker (1967), nor in our series in Birmingham.

DISTAL OBSTRUCTION

Our experience suggests that the perforation occurs during an acute exacerbation of Crohn's disease and was always associated with distal obstruction due to a chronic stenosing lesion. As can be seen from the Table the past histories range from three months to over six years and half of the patients had previous operative intervention for Crohn's disease. The perforations occurred in a diseased segment of bowel and were all proximal to diseased and narrowed bowel. These findings are in accordance with those described by Waye and Lithgow (1967), Nasr, Morowitz, Anderson, and Kirsner (1969), and Robinson and Craft (1967). Neely (1960) came to a similar conclusion despite the fact that in two of his cases the histories were less than 24 hours. Waye and Lithgow (1967) found, in their review of earlier reported cases, that a history consistent with the typical clinical course of Crohn's disease was unusual and that many of the patients presented with an acute episode without antecedent clinical illness and were frequently misdiagnosed. However, in spite of the short history, pathological findings in the affected area were consistent with chronic regional enteritis.

The most recent patient at emergency admission gave no suggestive features of previous illness but subsequently revealed weight loss, abdominal pain, and lassitude going back at least one year.

\section{SITE}

The perforation in reported series has almost invariably been in the ileum or jejunum. Nasr and his colleagues (1969), in their analysis of the 41 patients then reported, found that 29 were ileal and another three were probably also ileal but the exact site was not defined. Only three were in the jejunum and none was reported in the colon. The sites of perforation in our series confirm these findings. Two cases in our series are of interest in that a bypassed ileal loop perforation had been reported only once previously (Waye and Lithgow, 1967), as has a colonic perforation (Javett and Brooke, 1970).

\section{STEROIDS}

These have often been implicated as the reason why in the few cases perforation has occurred instead of the more usual fistulae or abscess formation. The steroids have been considered to contribute to a breakdown in immune defence mechanisms. However, despite the findings of Nasr and his colleagues (1969) that four of their five patients were on steroids, their review of the previous 36 cases showed that only two had or were receiving steroids. Of the 360 
patients at risk in this report 152 had received steroids. Our findings suggested that steroids are not an important factor in this complication.

\section{TREATMEN T}

The early reports of this complication emphasize the lack of uniformity regarding management. Neely (1960) noted in his report of six cases that each patient with an essentially similar problem was dealt with in a different manner. Certainly this is still typical of the overall inexperience in dealing with this condition and of the different methods of treatment in our series covering 30 years of experience.

Past analysis has shown poor results with simple closure with or without drainage. Of 13 patients reported before 1970 who were so treated, four died after operation, one died during a second operation for a re-perforation, and five required early reoperation. A more recent report (Menguy, 1972) of 11 cases showed that five died and three had serious postoperative complications.

An understanding of the pathology of this condition suggests the likely importance of the distal obstruction. We feel that it is a fundamental surgical principle to relieve this by removing the obstructed segment if re-perforation or fistula is to be prevented. Our conclusions based on the pathological and clinical evidence concur with those of previous writers (Waye and Lithgow, 1967; Graham and Baugh, 1968) that the optimum treatment is primary excision of the perforated segment and the distal diseased bowel.

The experience in this series is insufficient to answer the question as to whether a primary anastomosis can safely be performed. Waye and Lithgow (1967) and Graham and Baugh (1968) advocate primary anastomosis although Menguy (1972) showed that of 20 cases treated in this manner there were three deaths and one significant post- operative complication. There may be considerable merit in the suggestion of Menguy (1972) to undertake a double barrelled cutaneous ileocolostomy with later closure of the stoma. He reports eight cases with no mortality and only one significant postoperative complication. This technique, not without its technical difficulties and stomal problems, has the undoubted advantage of overcoming the need for anastomosis of bowel in the presence of a contaminated peritoneal cavity. This method should be given due consideration.

It was of interest to note that the incidence of this complication has decreased over the past decade (see Fig). It can be seen that the number of free perforations decrease as the number of elective operations for Crohn's disease has increased. Our conclusion is that the susceptible cases with obstructive tendency are possibly being diminished by surgical resection. This is in contrast to Menguy (1972) who felt that there was an increase in the number of perforations.

Perhaps the apparent increase merely reflects an increasing awareness of the condition.

\section{References}

Altman, A. D., Golden, D., Seidenberg, B., Kavee, D., and Parker, J. G. (1966). Free perforation in regional enteritis. Amer. J. dig. Dis., 11, 658-663.

Arnheim, E. E. (1935). Regional ileitis with perforation, abscess and peritonitis. J. Mt Sinai Hosp., 2, 61-63.

Atwell, J. D., Duthie, H. L., and Goligher, J. C. (1965). The outcome of Crohn's disease. Brit. J. Surg., 52, 966-972.

Banks, B. M., Zetzel, L., and Richter, H. S. (1969). Morbidity and mortality in regional enteritis. Amer. J. dig. Dis., 14, 369-379.

Crohn, B. B., Yarnis, H. (1958). Regional Enteritis, 2nd ed. Grune and Stratton, New York.

Crohn, B. B. (1957). Indications for surgical intervention in regional ileitis. Arch. Surg., 74, 305-311.

Gjone, E., Orning, O. M., and Myren, J. (1966). Crohn's disease in Norway, 1956-1963. Gut, 7, 372-374.

Gump, F. E., Lepore, M., and Barker, H. G. (1967). A revised concept of acute regional enteritis. Ann. Surg., 166, 942-946.

Graham, P. A., and Baugh, J. H. (1968). Perforation and peritonitis in regional enteritis. Amer. J. Surg., 115, 856-860.

Javett, S. L., and Brooke, B. N. (1970). Acute dilatation of colon in Crohn's disease. Lancet, 2, 126-128.

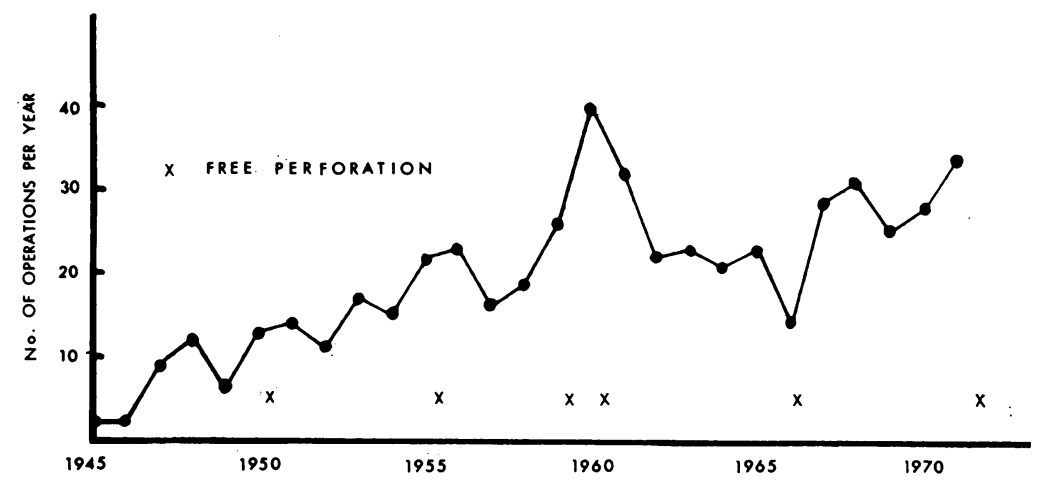

Fig. Year of occurrence of perforation is compared with number of operations per year from 1945 to 1972. 
Koutny, J. (1968). Expérience clinique et chirugicale dans 70 cas de maladie de Crohn. Acta chir. belg., 67, 981-1010.

Menguy, R. (1972). Surgical management of free perforation of the small intestine complicating regional enteritis. Ann. Surg., 175, 178-189.

Nasr, K., Morowitz, D. A., Anderson, J. G. D., and Kirsner, J. B. (1969). Free perforation in regional enteritis. Gut, 10, 206-208.
Neely, J. C. (1960). Perforation in regional enteritis. J. Amer. med. Ass., 174, 1650-1682.

Robinson, K. P., and Craft, I. L. (1967). Free perforation of the small bowel due to regional enteritis. Brit. J. Surg., 54, 799-801.

Schofield, P. F. (1965). The natural history and treatment of Crohn's disease. Ann. Roy. Coll. Surg. Engl., 36, 258-279.

Wave, J. D., and Lithgow, C. (1967). Small bowel perforation in regional enteritis. Gastroenterology, 53, 625-629. 